\title{
DNAJA1 wt Allele
}

National Cancer Institute

\section{Source}

National Cancer Institute. DNAJA1 wt Allele. NCI Thesaurus. Code C126987.

Human DNAJA1 wild-type allele is located in the vicinity of 9p13.3 and is approximately 15

$\mathrm{kb}$ in length. This allele, which encodes Dnaj homolog subfamily A member 1 protein, is involved in both protein folding and protein trafficking. 